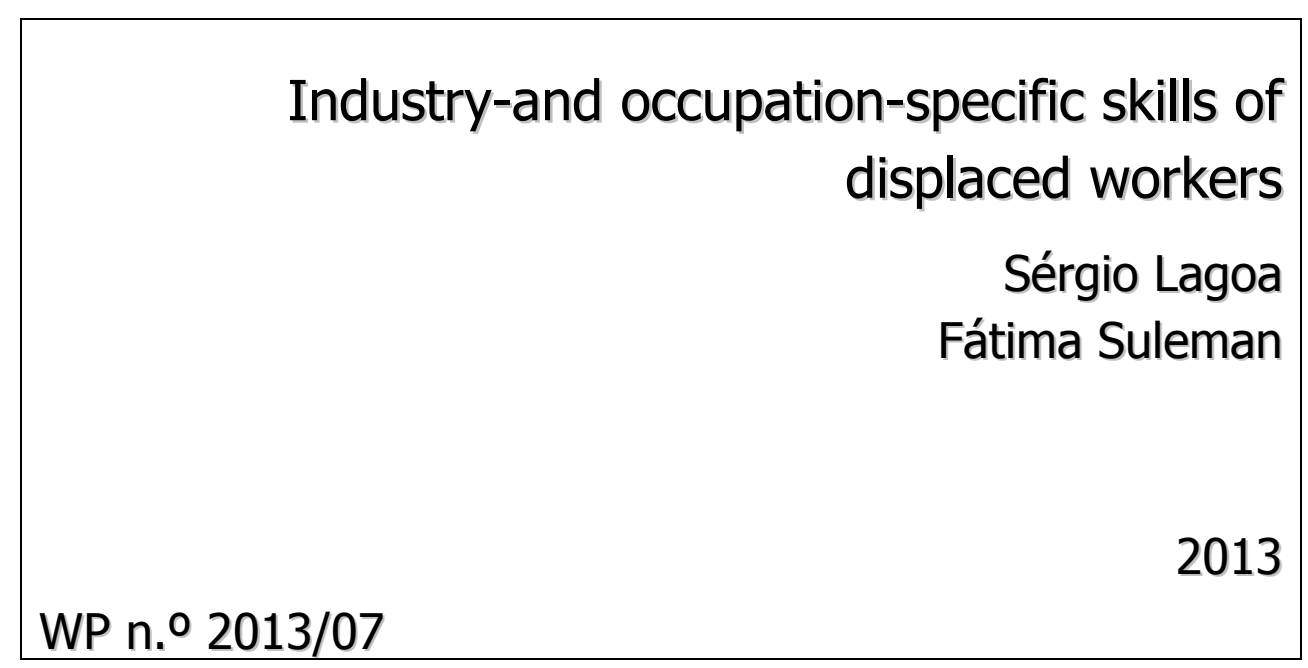

DOCUMENTO DE TRABALHO

WORKING PAPER

DINAMIA'CET 


\section{DINAMIR'CET}

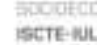

Industry-and occupation-specific skills of

displaced workers

Sérgio Lagoa*

Fátima Suleman**

WP n. ${ }^{0} 2013 / 07$

DOI: 10.7749/dinamiacet-iul.wp.2013.07

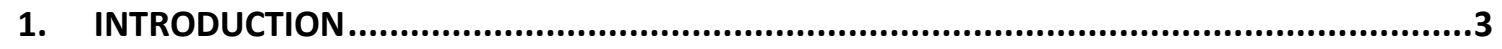

2. THE ROLE OF SPECIFIC SKILLS IN THE LABOUR MARKET ...........................................

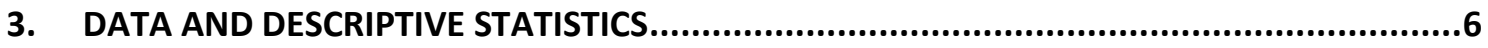

4. EMPIRICAL STRATEGY AND ECONOMETRIC MODEL .....................................................

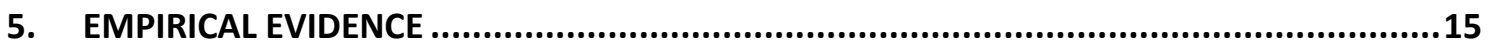

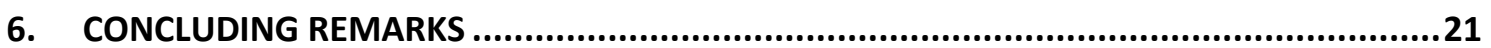

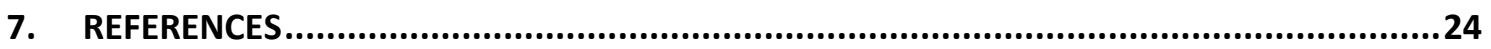

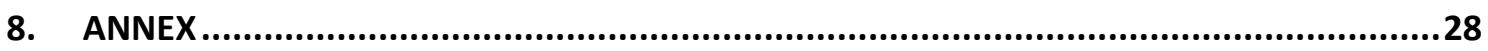

*DINÂMIA'CET - IUL and Dept. of Political Economy, ISCTE - University Institute of Lisbon (ISCTE-IUL), Portugal, sergio.Lagoa@iscte.pt.

** DINÂMIA'CET - IUL and Dept. of Political Economy, ISCTE - University Institute of Lisbon (ISCTE-IUL) Portugal, fatima.suleman@iscte.pt. 


\title{
Industry-and occupation-specific skills of
}

\author{
displaced workers ${ }^{1}$
}

\begin{abstract}
The role of marketable skills of workers has been the core focus of the human capital framework. Individuals accumulate skills that enhance their productivity and earnings, but sometimes they are forced to change their professional careers and find new jobs. This paper uses Portuguese linked employer-employee data - Quadros de Pessoal - and explores the relevance of industry and occupation specific skills by looking at the wage losses of displaced workers due to firms shutting down. Our empirical analysis considers the four alternatives that workers face after displacement namely changing both industry and occupation; changing industry and staying in the same occupation; changing occupation but staying in the same industry, or staying in the same industry and occupation. Empirical evidence suggests that for workers who switch industry/occupation, pre-displacement industry/occupation tenure implies a larger wage loss than for industry/occupation stayers. In a context of rising unemployment, our analysis allows us to suggest that when experienced workers are displaced and forced to find a job in a different industry, they suffer considerable wage cuts.
\end{abstract}

\footnotetext{
${ }^{1}$ Acknowledgments:

We gratefully acknowledge financial support from FLEX FCT grant PTDC/EGE ECO/108547/2008, 'Flexible wages for flexible contracts? The dynamics of the relationship between wage policy and employment contracts at the firm level'. The research was possible thanks to the kindness of the Office for Strategy and Studies (GEE), the Ministry of Economy and Employment for access to the data, Quadros de Pessoal. This article has benefited from the helpful comments of an anonymous referee and the participants at the 3rd LEED Conference, ISEG-UL.
}

DINÂMIA'CET - IUL, Centro de Estudos sobre a Mudança Socioeconómica e o Território ISCTE-IUL - Av. das Forças Armadas, 1649-026 Lisboa, PORTUGAL 


\section{INTRODUCTION}

Labour markets are characterised by a process of reallocation of workers across jobs and firms. When existing firms shut down, workers have to find new jobs and adjust skills to their postdisplacement jobs. The transferability of displaced workers' skills has attracted much attention among labour economists, as documented in several papers published since the late 1980s (e.g. Shaw, 1984; Neal, 1995; Kletzer, 1996; Sullivan, 2010). While it is assumed that industryspecific (Neal, 1995) or occupation-specific skills (Shaw, 1984) might be valuable for more than one employer, there is a lack of consensus regarding the reward for those skills in the labour market.

Our paper uses Portuguese linked employer-employee data - Quadros de Pessoal - and explores the relevance of industry-and occupation-specific skills by looking at the wage losses of displaced workers due to firms shutting down. Previous research has already explored this topic (e.g. Kambourov and Manovski, 2009; Zangelidis, 2008). However, the studies fail to account for different possible options after dismissal. For instance, displaced workers may change both industry and occupation; change industry but stay in the same occupation; change occupation but stay in the same industry, or stay in the same occupation and industry. While the first option constitutes a complex change, changing only industry or occupation seems to be less severe. This paper contributes to the literature by examining the impact of these different alternatives on post-displacement earnings in order to discuss differing degrees of wage losses, which allow conclusions to be drawn on the degree of transferability of skills.

The questions to be answered are: do industry- or occupation-specific skills create barriers to inter-industry mobility? Are industry and occupation specific skills rewarded by firms in the labour market? How large are the wage losses of displaced workers in each situation of industry and/or occupation change? We assume that wage losses vary according to the mobility options workers choose after dismissal. However, the destination job is important because some industries as well as some occupations tend to reward accumulated skills differently.

The examination of skill specificity/transferability helps labour market players and policy makers address a number of key issues. In the context of rising unemployment, workers should be informed about how to improve their situation in the labour market, and information on workers' productive skills is crucial for firms during the hiring process. Usually, displacements occur in specific industries or occupations, and therefore the chances of workers finding a new job in the same industry (or occupation) may be reduced. This contributes, partially or totally, to

DINÂMIA'CET - IUL, Centro de Estudos sobre a Mudança Socioeconómica e o Território ISCTE-IUL - Av. das Forças Armadas, 1649-026 Lisboa, PORTUGAL Tel. 210464031 - Extensão 293100 E-mail: dinamia@iscte.pt www.dinamiacet.iscte.pt 
rendering workers' accumulated skills useless, and at the same time may entail additional training costs.

All these associated costs challenge policy makers to undertake suitable labour market policies to avoid structural unemployment, promote the re-allocation of workers, and fight wage inequality and eventually to deal with long-term effects of displacement (Ohlsson and Storrie, 2012). Furthermore, Portugal provides an interesting case study as it is characterised by low job flows and low worker flows (Blanchard and Portugal, 2001; Andersen et al., 2008).

The remainder of the paper is organized as follows. The theoretical framework is explained in Section 2 before describing the data in Section 3. The econometric model is then presented in Section 4, followed by the empirical evidence in Section 5. Finally, Section 6 concludes.

\section{THE ROLE OF SPECIFIC SKILLS IN THE LABOUR MARKET}

Involuntary mobility and the reward displaced workers receive for accumulated skills have been a source of great interest for labour economists since the late 1980s (for a survey see Fallick, 1996; and Kletzer, 1996).This research programme aims to answer questions such as: how important are specific skills, and how are the earnings of displaced workers affected by these skills? A myriad of papers have approached the issue of transferability of skills by addressing wage changes associated with job mobility. The goal of this research was to produce knowledge on how wages are affected by the loss of investment in specific human capital resulting from moving industry or occupation.

The literature goes beyond the traditional contrasting between firm specific and general skills (Becker, 1964). For instance, Stevens (1994) designates transferable skills as an intermediate category of skills that is valued by more than one employer. Neal (1995) and Kletzer (1996) recognise industry-specific skills; Shaw (1984) explores occupation-specific skills; while Sullivan (2010) differentiates between occupation and industry-specific skills as examples of transferable skills. Lastly, for Lazear (2003) skills are general by their very nature. However, Lazear concludes that the tasks to be performed demand particular combinations of skills which convert general into specific skills.

This discussion has immediate implications for the measurement and relevance of transferable skills. There is a relationship between pre-displacement industry tenure and postdisplacement wages (Neal, 1995; Podgursky and Swaim, 1987; Addison and Portugal, 1989; Neal, 1995; Carneiro and Portugal, 2006). Evidence from a comparison between industry

DINÂMIA'CET - IUL, Centro de Estudos sobre a Mudança Socioeconómica e o Território ISCTE-IUL - Av. das Forças Armadas, 1649-026 Lisboa, PORTUGAL Tel. 210464031 - Extensão 293100 E-mail: dinamia@iscte.pt www.dinamiacet.iscte.pt 
stayers and industry switchers demonstrates that industry-specific skills play a major role in wages while firm-specific skills are of little importance (Neal, 1995).

However, evidence suggests that the reward attached to transferable skills varies according to the destination industry (Ong and Mar, 1992; Jacobson, LaLonde and Sullivan, 1993; and Cha and Morgan, 2010). In their study of semiconductor firms in Silicon Valley, Ong and Mar (1992) found that displaced workers who were reemployed in the same 4-digit SIC industry or other high-tech industries suffered no wage loss, while workers who found jobs outside the high-tech sector accepted a considerable cut in wages. For manufacturing workers, Jacobson, LaLonde and Sullivan (1993) found that the main determinant of wage loss after six years of displacement is whether he/she gets (or not) a job in the manufacturing sector, but the 4-digit SIC industry where the reemployment takes place is not relevant.

Kletzer (1996) provides further arguments and reaches a slightly different conclusion. Her empirical evidence suggests that the effect of job tenure on post-displacement wages depends on the origin and destination industries. For instance, in Trade and Finance and Services industry tenure prior to displacement has a higher reward than in other sectors, while re-employment in traditional low-wage industries leads to a wage loss as reported by Cha and Morgan (2010). Furthermore, Ong and Mar (1992) distinguish between reemployment in "close" and "far away" industries after displacement.

Literature also shows that the debate on transferable skills is not confined to displaced workers or restricted to industry-specific skills. For example, using a direct measure of industry tenure, Parent (2000) finds evidence that industry-specific skills have a much greater effect on wages than firm tenure. Other studies have considered different types of transferable skills, in particular occupation-specific skills (e.g. Kambourov and Manovskii, 2009); and Zangelidis, 2008), and compared the impact of both industry and occupation tenure on wages. Empirical evidence based on industry and occupational mobility is however inconclusive. Whereas Kambourov and Manovskii (2009) and Zangelidis (2008) stress the impact of occupation tenure, which reduces the effect of industry and firm specific tenure, Goldsmith and Veum (2002) and Sullivan (2010) found evidence of the relevance of both types of transferable skills for wages.

The above-mentioned literature provides considerable knowledge about wage dynamics associated with transferable skills. However, the relevance of both industry and occupation specific skills for displaced workers is under-explored in the literature. Furthermore, the studies overlook the choices workers have to make after displacement. For displaced workers, the loss in wage is more associated to the change in the portfolio of skills required to perform tasks than to the change of industry or occupation codes, as suggested by Poletaev and Robinson (2008).

DINÂMIA'CET - IUL, Centro de Estudos sobre a Mudança Socioeconómica e o Território ISCTE-IUL - Av. das Forças Armadas, 1649-026 Lisboa, PORTUGAL Tel. 210464031 - Extensão 293100 E-mail: dinamia@iscte.pt www.dinamiacet.iscte.pt 
It is necessary to determine whether the wages of displaced workers are affected by their choice to stay in the same industry/occupation or to change industry/occupation. The research hypothesis to be tested empirically is that both industry and occupation-specific skills impact the wages of displaced workers. Therefore, the interaction between different moves may be relevant. Those who experience complex changes would face higher wage losses than displaced workers that remained in at least the same industry or occupation.

\section{DATA AND DESCRIPTIVE STATISTICS}

To estimate the impact of industry and occupation specific skills on the earnings of displaced workers, we use Portuguese linked employer-employee data - Quadros de Pessoal, a census of all firms operating in the Portuguese private sector and with at least one worker (for details see Lima and Pereira, 2003; Cardoso and Portugal, 2005; and Cardoso and Portela, 2009). Our analysis is restricted to workers who were displaced following the shutting down of a firm between 1996 and $2008\left[^{2}\right]$. We consider a firm as having closed if it disappears completely from the dataset within the period of our research. Additionally, we controlled for workers in firms involved in mergers and acquisitions. Displaced workers in our sample should report a different entry date for the new and previous firm; and the date of displacement must be before the entry date in the new firm. If this is not the case, it probably indicates a move between firms involved in a merger or acquisition process (Martins, 2007).

The study focuses on 12 years with around 200,000 observations of full time displaced workers from the non-farm private sector. Our goal is thus to explain the change in (log) wages of displaced worker, which is a worker with a new job in year $t$ and whose firm has closed in the same year or before. While information on worker characteristics are available in the dataset, e.g. age, gender, education level, occupation, firm tenure, wages and other regular and irregular payments, working hours, other variables require some calculations.

The hourly real wage was obtained from the total wage, which corresponds to the sum of the following monthly values: base wage (gross pay for normal hours of work), regular benefits (including tenure-related pay), irregular benefits (including productivity bonuses and profit- or performance related pay), and over-time pay. Accordingly, the total amount of hours worked is the sum of normal hours and overtime hours per month. The hourly wage was obtained by

${ }^{2}$ We chose 1996 as the starting date because a revised national occupational standard classification became available and was used in the database.

DINÂMIA'CET - IUL, Centro de Estudos sobre a Mudança Socioeconómica e o Território ISCTE-IUL - Av. das Forças Armadas, 1649-026 Lisboa, PORTUGAL Tel. 210464031 - Extensão 293100 E-mail: dinamia@iscte.pt www.dinamiacet.iscte.pt 
dividing total wage by total hours. The CPI was used to deflate the hourly wage so as to obtain the real wage in 1995 euros $\left[{ }^{3}\right]$. In order to measure the impact of the business cycle on wages we used the aggregated unemployment rate from the National Statistical Office (INE).

We use industry tenure as a proxy of industry-specific skills. Using the same strategy as Kambourov and Manovskii (2009), the industry tenure variable for a worker was set equal to firm tenure in the first year he/she was registered in the database. In the subsequent years, we accumulate the years a worker was employed in a given industry (identified through the onedigit industry code). $\left[{ }^{4}\right]$ If a worker leaves an industry and then returns, we take into account his/her previous experience in the industry. In other words, we construct our measure of industry tenure using all employment spells: the total time a worker was in an industry is considered, even if the worker was not continuously in the industry. $\left[{ }^{5}\right]$

The same approach was applied to calculate occupation tenure. We used the Standard Classification of Occupations (CNP) $\left[^{6}\right]$ and calculated how many years the worker stayed at the same occupational level (2-digit), making use of all employment spells. $\left.{ }^{7}\right]$ For all other types of skills including general skills, we used the traditional human capital approach. As usual, years of schooling and labour market experience proxy general skills in our study.

The dataset also includes information on employers. For the purpose of this paper, we consider the most commonly used variables in the literature, such as the size of the firm (measured by the number of workers) and sales per worker (at 1995 prices) (Brown and Medoff, 1989; Abowd et al., 1999).

Table A1 and A2 (in annex) displays summary statistics. $\left[{ }^{8}\right]$ We observe that there is an over-representation of manufacturing and construction as pre-displacement industries; together they represent $52.65 \%$ of the sample, while industrial activities only represented $33 \%$ of the overall non-farm employment in 2008 (according with Data from National Statistical Office

\footnotetext{
${ }^{3}$ As the survey was conducted in October of each year after 1993, we used the CPI of October of the respective year.

${ }^{4}$ See Annex for details on industry codes.

5 This approach eliminates less of the variance in industry tenure necessary to identify this variable, and does not assume a very quick depreciation of industry-specific skills (Zangelidis, 2008). Necessarily, this measure understates the true sector tenure because we do not know what happened before the first job registered in the database (1986).

6 The Portuguese occupation classification adopts the same nine level structure as the International Classification of Occupations (ISCO).

${ }^{7}$ This calculation started in 1995 when a new classification of occupations was launched. In 1995, we set the occupation tenure equal to one for all workers.

${ }^{8}$ We excluded the $1 \%$ top and bottom outliers in terms of wage change. DINÂMIA'CET - IUL, Centro de Estudos sobre a Mudança Socioeconómica e o Território ISCTE-IUL - Av. das Forças Armadas, 1649-026 Lisboa, PORTUGAL Tel. 210464031 - Extensão 293100 E-mail: dinamia@iscte.pt www.dinamiacet.iscte.pt
} 
(INE)). These figures might be related with economic slowdown in these sectors with the consequent closing down of firms and employment reduction.

A closer look at pre- and post-displacement employment dynamics offers contrasting findings (Table A2 in annex). Manufacturing has lost the largest proportion of workers whereas real estate and services to firms and collective and social services show the largest relative increase. This translates the overall tendency for tertiarization of the economy and more specifically the growth of real estate industry during the period under study.

Furthermore, skilled and craft occupations especially linked to industrial occupations suffered the largest relative loss of workers (-2.5 p.p.) from the pre- to the post-displacement moment - Table A3 in annex. By contrast, unskilled occupations had the largest increase of workers (+1.6 p.p.).

In addition, our sample offers interesting features (Table A1). For example, $43 \%$ of workers are women; workers stay without job by 1.1 years on average (but the standard deviation is relatively large); and workers tend to move to larger firms (with a work force $124 \%$ larger), but that have a lower labour productivity (less $10.4 \%$ on average).

Table 1 - Characterisation of workers by type of decision

\begin{tabular}{|c|c|c|c|c|}
\hline & $\begin{array}{c}\text { 1 Change Industry } \\
\text { | Change } \\
\text { occupation }\end{array}$ & $\begin{array}{c}\text { 2 Change Industry } \\
\text { | Stay occupation }\end{array}$ & $\begin{array}{c}\text { 3 Stay industry | } \\
\text { Change } \\
\text { occupation }\end{array}$ & $\begin{array}{c}\text { 4 Stay industry | } \\
\text { Stay occupation }\end{array}$ \\
\hline No. workers & 44529 & 20729 & 39505 & 96015 \\
$\%$ total & $22.3 \%$ & $10.3 \%$ & $19.6 \%$ & $47.6 \%$ \\
Industry tenure & 4.62 & 4.66 & 5.93 & 6.44 \\
Occupation tenure & 2.55 & 3.23 & 2.75 & 3.53 \\
Firm tenure & 3.87 & 3.88 & 4.46 & 4.47 \\
Labour market & 16.17 & 18.40 & 17.67 & 19.15 \\
experience & 8.27 & 8.32 & 7.87 & 6.94 \\
Years of school & & &
\end{tabular}

Descriptive statistics in Table 1 indicate that $47.6 \%$ of displaced workers stay in the same industry and occupation, while $22.3 \%$ change both occupation and industry. Furthermore, $19.6 \%$ of workers change occupation within the same industry; while changing industry but staying in the same occupation is the least common choice for workers (10.3\%). Employees are more mobile across occupations than industries: $41.9 \%$ change occupation and only $32.6 \%$ change industry.

DINÂMIA'CET - IUL, Centro de Estudos sobre a Mudança Socioeconómica e o Território ISCTE-IUL - Av. das Forças Armadas, 1649-026 Lisboa, PORTUGAL 
In addition, there are some stylised facts (Farber, 1999) that we can observe in the Portuguese labour market. For example, tenure affects negatively mobility since stayers have on average higher tenure than switchers. Firstly, average occupation tenure for occupation stayers is 3.53 years (if they stay in the same industry) or 3.23 (if they change industry), while it is 2.75 years for occupation changers in the same industry, and 2.55 years in a different industry. Secondly, average industry tenure of industry stayers is 6.44 (if they stay in the same occupation) or 5.93 (if they change occupation), whereas for industry changers it is around 4.6 years regardless whether they change or not occupation. At first glance, these findings suggest that firms reward industry and occupation specific skills, and that poorly endowed workers (in terms of the several types of tenure) tend more to find jobs outside the industry or occupation of origin.

Movers and stayers also differ in other important characteristics. Workers that do not change occupation and industry, or only change occupation have an average firm tenure of around 4.5 years. This figure is larger than the ones observed for workers that change both industry and occupation, or only industry (3.87 years and 3.88 years, respectively).

Industry and occupation stayers tend to have more labour market experience (an average of 19.15 years), whereas industry and occupation changers have the lowest labour market experience (16.17 years). Individuals that move industry and stay in the same occupation, and the ones that only change occupation have an average experience of 18.4 years and 17.67 years respectively, which places them in the middle of the two first extreme cases.

Differently from Lima (2003) and Garcia Pérez and Rebollo Sanz (2005), our findings suggest that movers are more educated. Workers that move occupation and industry, or move only industry are the most educated (around 8.3 years of schooling), while stayers in the same industry and occupation have the lowest level of education (6.9 years of schooling). In sum, comparatively to occupation and industry stayers, changers are more educated but have lower tenure and labour market experience. In conclusion, that mobility occurs early in careers is one more stylised fact that we found in the data.

Furthermore, mobility patterns by pre-displacement industry indicate that mobility varies across industries (Table A4 in annex). While workers from extractive industries, restaurants and hotels, and real estate and services to firms present higher mobility, they are less likely to move from industries like banking and finance, construction, and manufacturing.

Looking now at the mobility of displaced workers by pre-displacement occupation (Table A5 in annex), we observe that workers in occupations as managers, middle managers and technicians, and also unskilled workers have the largest mobility, which contrasts with the

DINÂMIA'CET - IUL, Centro de Estudos sobre a Mudança Socioeconómica e o Território ISCTE-IUL - Av. das Forças Armadas, 1649-026 Lisboa, PORTUGAL Tel. 210464031 - Extensão 293100 E-mail: dinamia@iscte.pt www.dinamiacet.iscte.pt 
lowest mobility in occupations of skilled workers and craftsmen, service and sales workers, machine operators and assembly workers.

\section{EMPIRICAL STRATEGY AND ECONOMETRIC MODEL}

First and foremost, our study focuses on workers who are forced to move due to plant closure. By doing this, we tried to eliminate the endogeneity related to the worker's decision to change firm. A worker is deemed to have been made redundant when dismissal was caused by firms closing down and does not depend on his/her performance or decision. The reason for mobility is therefore exogenous.

Our purpose is to identify how pre-displacement industry and occupation tenures affect the salaries of displaced workers in their new jobs. The following model log wage change in $t$ for worker $i$ is considered:

$$
\Delta \mathrm{w}_{\mathrm{it}}=\beta_{0}+\beta_{1} \text { tnind }_{\mathrm{it}-\mathrm{m}}+\beta_{1} \text { tnocup }_{\mathrm{it}-\mathrm{m}}+\beta_{3} \mathrm{x}_{\mathrm{it}}+\mathrm{e}_{\mathrm{it}}
$$

where $\Delta \mathrm{w}_{\mathrm{it}}$ is the log difference between the wage in the job obtained after displacement and the wage in the job before displacement, tnind $_{\text {it-m }}$ is industry tenure of worker i before being displaced $\mathrm{m}$ years ago, tnocup $\mathrm{it}_{\mathrm{it}} \mathrm{m}$ is the tenure in occupation before being displaced, and $\mathrm{e}_{\mathrm{it}}$ is a random error. $\left[{ }^{9}\right]$ Notice that the worker's fixed effect was removed by differentiating wages. The vector $\mathrm{x}_{\mathrm{it}}$ includes the characteristics of individuals (sex, years of schooling, predisplacement firm tenure $\left[{ }^{10}\right]$ and its square, pre-displacement potential labour market experience and its square, the number of years since displacement), of firms (log difference between the number of employees and sales per worker of the new firm and the predisplacement firm) and of jobs (the new and old occupation level and the new and old industry) $\left[{ }^{11}\right]$, the difference between industry wage premiums in the new and pre-displacement industry, the change in the unemployment rate and a time trend.

The control variables are the usual ones used in the literature to explain wages. We expect a gender wage gap in the returns to job mobility (Bono and Vuri, 2011). Moreover,

\footnotetext{
${ }^{9}$ We also include the square of trind $d_{\text {it }-m}$ and tnocup $_{\text {it }-m}$.

${ }^{10}$ Notice that in the year workers find a new job, current firm tenure is always equal to or less than one year. Then, only tenure in the old firm varies.

${ }^{11}$ In cases where the new and old occupation (industry) coincide, only one occupation (industry) is considered.

DINÂMIA'CET - IUL, Centro de Estudos sobre a Mudança Socioeconómica e o Território ISCTE-IUL - Av. das Forças Armadas, 1649-026 Lisboa, PORTUGAL Tel. 210464031 - Extensão 293100 E-mail: dinamia@iscte.pt www.dinamiacet.iscte.pt
} 
unemployment rate has probably a negative effect on wages since they tend to be pro-cyclical (Deveraux and Hart, 2006). In turn, the number of years since displacement has an uncertain impact on wages. On the one hand, more time to get a new job will probably originate a better employee-employer match, but on the other hand may imply a devaluation of acquired skills. However, Kletzer (1996) finds a positive coefficient for this variable.

To investigate the impact of firms' characteristics, we consider the difference in the number of employees and sales per worker between the pre- and post-displacement firms, which are expected to have a positive effect on wage changes because large and more productive firms tend to pay higher wages (Brown and Medoff, 1989; Abowd et al., 1999). Finally, we include dummies for pre- and post-displacement occupations and industries inasmuch as workers accumulate additional specific skills from other sources (that are not captured by job tenure), namely from vocational training off the job - examples are machining and computer skills (Kletzer, 1996).

The inclusion of industry wage premiums is related with the fact that differences in wages between industries may occur due to rents originated by union activity, market power in the product market and efficiency wages. As a result, if a worker switches to a high-premium industry, his/her wage will increase independently of his/her industry or occupation skills, in other words, wages of displaced workers may change simply due to differences in wage premiums across industries. For this purpose, sectorial wage premiums were obtained from the coefficient of industry dummies in a cross-sectional wage regression performed for each year and for all workers in Quadros de Pessoal (and not only the displaced workers), with the same controls as in (1). Then, we used the difference in wage premiums between the worker's new industry and the pre-displacement industry as the explanatory variable of the wage change. When a worker stays in the same sector, this variable only captures the change in industry wage premium across time.

While years of schooling and potential labour market experience measure general skills, specific skills are proxied by pre-displacement firm, industry and occupation tenures. Years of schooling are expected to have a positive effect on wage growth since more educated workers can learn easily and adapt better to the labour market (Thurow, 1976). The impact of labour market experience and tenures is expected to be negative because there is a negative relationship between wage level and wage growth (Neumark and Taubman, 1994), and workers with less experience and tenure tend to have smaller wage levels. The arguments for a negative sign of the coefficient of firm tenure are further reinforced by the loose of all firm-specific skills of displaced workers. This means that the coefficients $\beta_{1}$ and $\beta_{2}$ per se do not shed light on the 
value of industry or occupation skills. In order to evaluate the effect of industry and occupation tenures on wages, it is necessary to compare the impact of tenure on the wages of workers who switch industry/occupation with the wage of workers who stay in the same industry/occupation. The negative effect of tenure on wages is expected to be smaller if the worker stays in the same industry/occupation than if he/she switches industry/occupation. This occurs because industry/occupation switchers get no return on industry tenure unlike stayers. Notice that $\beta_{1}$ or $\beta_{2}$ are not related with firm tenure since by definition displaced workers move to a new firm.

Given that it is necessary to compare the wage of switchers with the wage of stayers, we estimate equation (1) in four situations: (1) workers moving sector and occupation, (2) workers moving sector but maintaining occupation, (3) workers staying in the same sector but changing occupation, and (4) workers staying in the same sector and occupation.

Our analysis allows us to test for the interaction between occupation- and industryspecific skills by looking, for example, at the relevance of industry skills when a worker changes occupation or stays in the same occupation. If the return of industry skills remains the same in both situations, then there is no interaction between industry and occupation skills. But if the return of industry skills is different in those two situations, then there is an interaction between industry and occupation skills. For instance, if occupation tenure implies a larger wage loss when a worker changes occupation and industry than when he/she changes only occupation, it means that part of the occupation skills are linked to industries.

In equation (1), the quality of job match was largely captured by the (removed) fixed effect, which captures the worker's ability. Indeed, workers with high levels of unobserved ability are likely have better job matches. Nevertheless, job match quality may not be completely explained by individual ability and can be correlated with industry or occupation tenure. More industry or occupation experience may enable the worker to find a better job match, as a result of more accumulated human capital and time of search. In this case, the estimation of $\beta_{1}$ and $\beta_{2}$ suffers from endogeneity bias. But when we compare the effect of tenure for stayers and switchers in industry/occupation, the difference in $\beta_{1}\left(\beta_{2}\right)$ is probably explained by industry/occupation skills and not by the correlation between tenure and the job match component, since there is no reason for that correlation to be different for switchers and stayers.

DINÂMIA'CET - IUL, Centro de Estudos sobre a Mudança Socioeconómica e o Território ISCTE-IUL - Av. das Forças Armadas, 1649-026 Lisboa, PORTUGAL 


\section{Selection bias}

Selection bias may exist in the estimation of equation (1) because the decision to stay or move to another sector or occupation may be related with unobservable components of wages. Since workers can choose from four alternatives, we use a multinomial logit model to correct the selection bias (Bourguignon et al., 2007). Firstly, a multinomial model is estimated for the choice of switching sector and occupation taking into account the four alternatives available. Secondly, the equation for wage is estimated adding a selectivity correction term obtained in the first step.

Interestingly, the logit model permits another way of testing the relevance of specific skills. If industry/occupation tenure is positively related with the choice to stay in the same sector/occupation, then we can conclude that there are industry/occupation specific skills.

As explained, there are four choices for worker $i, \mathrm{j}=1, \ldots, 4$. If option $c$ is chosen, the wage equation is:

$$
\Delta w_{c i t}=\beta_{1} \text { tnind }_{i t-m}+\beta_{2} \text { tnocup }_{i t-m}+\beta_{3} \boldsymbol{x}_{i t}+u_{c i t}
$$

"Utility" of option $\mathrm{j}$ is:

$$
y^{*}{ }_{j i t}=\gamma_{1} \text { tnind }_{i t-m}+\gamma_{2} \text { tnocup }_{i t-m}+\gamma_{3} z_{i t}+\eta_{j i t}, \mathrm{j}=1, \ldots, 4
$$

, with $\mathrm{z}_{\mathrm{it}}$ as the vector of variables determining the choice between alternatives.

Now define $\boldsymbol{x}_{i t}^{\prime}=\left\{\boldsymbol{x}_{i t}\right.$, tnind $_{i t-m}$, tnocup $\left._{i t-m}\right\}$ and $\boldsymbol{z}_{i t}^{\prime}=\left\{\boldsymbol{z}_{i t}\right.$, tnind $_{i t-m}$, tnocup $\left._{i t-m}\right\}$, with $\mathrm{E}\left(u_{c i t} \mid \boldsymbol{x}^{\prime}{ }_{i t}, \mathbf{z}^{\prime}{ }_{i t}\right)=0$.

Variable $\Delta w_{c i t}$ is only observed if choice $c$ is selected, which happens when the "utility" of that option is greater than the utility of any other option:

$$
y_{c i t}^{*}>\max \left(y^{*}{ }_{j i t}\right), j \neq c
$$

Define $\varepsilon_{c i t}=\max \left(y^{*}{ }_{j i t}-y^{*}{ }_{c i t}\right)$, for $\neq c$. Then, saying $c$ is chosen is the same as saying $\varepsilon_{\text {cit }}<0$.

The probability of a worker choosing $\mathrm{c}, P_{\text {cit }}$, is modelled by a multinomial model:

DINÂMIA'CET - IUL, Centro de Estudos sobre a Mudança Socioeconómica e o Território ISCTE-IUL - Av. das Forças Armadas, 1649-026 Lisboa, PORTUGAL Tel. 210464031 - Extensão 293100 E-mail: dinamia@iscte.pt www.dinamiacet.iscte.pt 


$$
P_{c i t}=\mathrm{P}\left(\varepsilon_{c i t}<0 \mid \mathbf{z}^{\prime}{ }_{i t}\right)=\frac{\exp \left(\mathbf{z}^{\prime}{ }_{i t} \gamma_{c}\right)}{\sum_{j} \exp \left(\mathbf{z}^{\prime}{ }_{i t} \gamma_{j}\right)} .
$$

The problem of estimating (1) arises because $u_{\text {cit }}$ may not be independent of $\eta_{\text {cit }}$ (Bourguignon et al., 2007). As a result, the explanatory variables may not be independent of the error term in equation (1).

Define $\Gamma=\left\{\mathbf{z}^{\prime}{ }_{i t} \gamma_{1}, \ldots, \mathbf{z}^{\prime}{ }_{i t} \gamma_{4}\right\}$. It follows that the conditional mean $\mathrm{E}\left(u_{c i t} \mid \varepsilon_{c i t}<0, \Gamma\right)=$ $\lambda(\Gamma)$.

The consistent estimate of the 's is obtained running OLS in (1) incorporating $\lambda(\Gamma)$ :

$$
\Delta w_{\text {cit }}=\beta_{1} \text { tnind }_{i t-m}+\beta_{2} \text { tnocup }_{i t-m}+\beta_{3} x_{i t}+\lambda(\Gamma)+z_{c i t}
$$

The error term $z_{\text {cit }}$ is now independent of the regressors.

Under the Lee linearity assumption, $u_{c i t}$ and $\Phi^{-1}\left(P_{c i t}\right)$ are linearly correlated with correlation $\rho_{c}: \mathrm{E}\left(u_{c i t} \mid \varepsilon_{c i t}, \Gamma\right)=-\sigma \rho_{c} \Phi^{-1}\left(P_{c i t}\right)$, with $\Phi$ as the standard normal cumulative distribution and $\sigma$ the standard deviation of $u_{c i t}$.

Then,

$$
\lambda(\Gamma)=-\sigma \rho_{c} \frac{\phi\left(\Phi^{-1}\left(P_{c i t}\right)\right)}{P_{c i t}}
$$

, with $\phi$ as the standard normal density function.

In sum, first it is necessary to estimate the $\phi$ 's, and next use them to estimate $m_{c i t}=$ $\frac{\phi\left(\Phi^{-1}\left(P_{c i t}\right)\right)}{P_{c i t}}$. After, the last expression is used in (2) to obtain a consistent estimate of the $B^{\prime} s$ and $\sigma \rho_{c}$ by OLS.

We assume that the model is non-parametrically identified, with some of the variables determining the choice between alternatives $\left(\mathbf{z}_{i t}\right)$ excluded from the wage equation (i.e. excluded from $\left.\boldsymbol{x}_{i t}\right)$. In other words, it is necessary that some variables related with the decision to switch industry or occupation are not related with wage change. We have chosen the (log) employment in the pre-displacement industry and also the $(\log )$ employment in the predisplacement occupation. These variables are expected to be inversely related with the decision to switch industry/occupation because the cost of searching for a new job in the worker's previous industry/occupation is smaller if there are many jobs available in that industry/occupation. Moreover, the level of employment in the pre-displacement industry/occupation is not expected to be related with post-displacement wages.

DINÂMIA'CET - IUL, Centro de Estudos sobre a Mudança Socioeconómica e o Território ISCTE-IUL - Av. das Forças Armadas, 1649-026 Lisboa, PORTUGAL Tel. 210464031 - Extensão 293100 E-mail: dinamia@iscte.pt www.dinamiacet.iscte.pt 


\section{EMPIRICAL EVIDENCE}

\subsection{The decision to switch}

The result of our econometric analysis focuses on the decision to switch. Table 2 reports the estimates of multinomial logistic regression and offers the impact of different kinds of skill on the decision to switch, namely, industry and occupation tenure, labour market experience and schooling.

Table 2

The impact of skills on the decision to move

\begin{tabular}{|l|l|l|l|}
\hline & $\begin{array}{l}\text { Option 1: } \\
\text { Move industry } \mid \\
\text { Move occupation }\end{array}$ & $\begin{array}{l}\text { Option 2 } \\
\text { Move industry | Stay } \\
\text { occupation }\end{array}$ & $\begin{array}{l}\text { Option 3 } \\
\text { Stay industry | Move } \\
\text { occupation }\end{array}$ \\
\hline Industry tenure & $\begin{array}{l}0.881 * * * \\
(0.0039)\end{array}$ & $\begin{array}{l}0.809 * * * \\
(0.0044)\end{array}$ & $\begin{array}{l}1.029 * * * \\
(0.0044)\end{array}$ \\
\hline Occupation tenure & $\begin{array}{l}0.724 * * * \\
(0.0077)\end{array}$ & $\begin{array}{l}1.022 * * * \\
(0.0130)\end{array}$ & $\begin{array}{l}0.688 * * * \\
(0.0071)\end{array}$ \\
\hline Potential labour market & $1.012 * * *$ & $1.048 * * *$ & 0.996 \\
experience & $(0.0028)$ & $(0.0036)$ & $(0.0028)$ \\
\hline Years of schooling & $1.037 * * *$ & $1.045 * * *$ & $1.003 * * *$ \\
& $(0.0028)$ & $(0.0035)$ & $(0.0027)$ \\
& & & \\
\hline
\end{tabular}

We present the impact on the odds ratio of one additional year of tenure, experience or years of schooling (departing from zero years). The variables included in $\mathbf{x}_{1 \mathbf{t}}$ (eq. 1) are also considered, together with the $(\log )$ employment in the industry predisplacement and also the (log) employment in the pre-displacement occupation. Obs.: 200778, Log likelihood:-214285.43, Pseudo R2: 0.1401, LR chi2(144) $=69804.98(0.0000)$. Coefficients' standard errors in brackets. Significance of the coefficients: $* * *$ - significant at $1 \%, * *$ - significant at $5 \%$.

The multinomial logit allows us to assess the impact of tenure on the decision to switch occupation or industry. Industry tenure has a negative effect on the probability of changing sector whether or not there is a change of occupation. For instance, compared with staying in the same sector and occupation, a one year increase in industry tenure (from an initial tenure of zero) makes the odds ratio of changing sector (and staying in the same occupation) 0.81 times the odds ratio before the increase, i.e., the odds ratio reduces by $19 \%$ (Table 2). In contrast, industry tenure has a positive effect on the probability of staying in the same sector (and changing occupation). This finding indicates that industry specific skills increase the likelihood of job opportunities in the current industry.

In addition, the increase in industrial tenure reduces the odds ratio of switching sector more if the worker does not change occupation: if the worker changes occupation, a unitary increase in industry tenure reduces the odds ratio of changing sector by $11 \%$; on the other hand, an increase

DINÂMIA'CET - IUL, Centro de Estudos sobre a Mudança Socioeconómica e o Território ISCTE-IUL - Av. das Forças Armadas, 1649-026 Lisboa, PORTUGAL 
in industry tenure reduces the odds ratio by $19 \%$ if the worker does not change occupation. In other words, an increase in industry tenure tends to prevent a switch in industry more when workers do not change occupation than when they do.

Similarly, occupation tenure also reduces the probability of changing occupation. In the case of a worker changing occupation but staying in the same sector, a one year increase in occupation tenure reduces the odds ratio of changing occupation by $31.1 \%$, whereas the odds ratio falls by $27.5 \%$ if he changes occupation and sector. This illustrates the relevance of occupation-specific skills. Notice that the impact of occupation tenure on the odds ratio is quite similar whether or not the worker switches sector. Comparing with similar results for industry tenure, we observe that occupation tenure has a greater impact on preventing workers from changing occupation than industry tenure has on preventing workers from switching industry.

Until now, our focus has been on industry- or occupation- specific human capital. The question now is how general human capital influences a worker's decision to change job. Dolton and Kidd (1998) show that individuals who invest more in general human capital are more likely to change firms or occupations. In order to test the role of general human capital in the decision to change industry or occupation, we use years of schooling and total labour market experience. Estimation results indicate that broad human capital is important to explaining why workers change industry, but it is relatively insignificant in explaining why they change occupation. One additional year of school increases the odds ratio of changing sector and staying in the same occupation relative to the base choice by $4.5 \%$, while it has a statistically insignificant impact on the decision to change occupation and to stay in the same sector. Moreover, an additional year of total labour market experience increases the probability of changing sector and staying in the same occupation by $4.8 \%$, whereas the impact on the odds ratio of changing occupation in the same sector is negative, but not statistically significant.

The overall picture reported illustrates that displaced workers try to capitalise on their accumulated skills. This is to say, the higher their investments in specific skills, the lower the propensity to engage in radical changes. However, occupation-specific skills impose greater restrictions on change than industry-specific skills.

\subsection{Specific skills and earnings}

Another result of our empirical analysis concerns the impact of industry and occupation specific skills on earnings. The estimates reported in Table 3 indicate that the previous industry tenure does not have a statistically significant effect on a worker's wage when he/she stays in the same industry. In contrast if a worker switches industry and maintains the same occupation, five years 
of industry tenure imply a $3.2 \%$ decline in log wages. This evidence suggests the relevance of industry skills in that when a worker switches industry he/she suffers a decline in wages due to the loss of his/her industry-specific skills.

Table 3 - Log wage loss of displaced worker

\begin{tabular}{|l|l|l|l|l|}
\hline \multicolumn{1}{|c|}{ Option } & $\begin{array}{l}5 \text { years of } \\
\text { industry } \\
\text { tenure }\end{array}$ & $\begin{array}{l}\text { 5 years of } \\
\text { occupation } \\
\text { tenure }\end{array}$ & $\begin{array}{l}\text { 5 years of firm } \\
\text { tenure }\end{array}$ & $\begin{array}{l}5 \text { years of } \\
\text { labour market } \\
\text { experience }\end{array}$ \\
\hline $\begin{array}{l}\text { 1 Change Industry | Change } \\
\text { occupation }\end{array}$ & $-0.024^{* * *}$ & $-0.040^{* * *}$ & 0.0032 & $-0.0246^{* * *}$ \\
$(0.0079)$ & $(0.0065)$ & $(0.5609)$ & $(0.0000)$ \\
\hline 2 Change Industry | Stay & $-0.032^{* *}$ & -0.018 & -0.0052 & $-0.0176^{* *}$ \\
occupation & $(0.020)$ & $(0.3101)$ & $(0.4253)$ & $(0.0135)$ \\
\hline 3 Stay industry | Change & -0.0038 & $-0.0600^{* * *}$ & 0.0066 & $-0.0228^{* * *}$ \\
occupation & $(0.5548)$ & $(0.0001)$ & $(0.1322)$ & $(0.0000)$ \\
\hline 4 Stay industry | Stay occupation & -0.0012 & -0.0160 & $0.0052^{*}$ & $-0.0136^{* * *}$ \\
& $(0.7574)$ & $(0.1236)$ & $(0.0744)$ & $(0.0000)$ \\
\hline
\end{tabular}

Notes: $p$-values in parenthesis. The variables included in $\mathbf{x}_{1 \mathrm{t}}$ (eq. 1) are also considered. The multnomial logit model was used to correct selection bias. $* * *$ - significant at $1 \%, * *$ - significant at $5 \%$.

Interestingly, if a worker changes industry and occupation, five years of industry tenure imply a $\log$ wage decline of only $2.4 \%$. Notably, this decline is smaller than the one occurring when a worker changes industry but maintains his occupation (3.2\%), indicating that a displaced worker benefits from adjusting his/her occupation when moving industry. This contradicts our initial hypothesis that radical changes impose large wage losses. We had already seen a similar effect above when we observed that industry tenure has a smaller effect on preventing a worker switching industry when he also changes occupation than when he/she stays in the same occupation.

Regarding occupation tenure, results also indicate that occupation skills accumulate with experience. This is evident when we observe that pre-displacement occupation tenure does not have a statistically significant effect on wages if a worker does not change industry and occupation, but implies a decline in wage when the worker changes occupation and stays in the same industry. In the latter case, a worker with 5 years of occupation tenure loses $6.0 \%$ of his log wage.

Another relevant result is that 5 years of occupation tenure implies a loss in wage of only $4 \%$ if a worker changes occupation and industry simultaneously. This loss is smaller than if the worker only changes the occupation. In combination with the results above, we conclude that workers benefit more from changing occupation and sector simultaneously than from changing only sector or occupation. One possible explanation may be the fact that workers are leaving industries stagnating or in decline (Markey and Parks, 1989), and their previous 
occupations are not valued in the new destiny industries, and so they benefit from moving to new occupations better adjusted to the new industries.

Total experience has a small negative impact on wage growth that is quite consistent across the four models. Five years of total experience implies a decrease in wages that ranges from $1.3 \%$ in model 4 to $2.4 \%$ in model 1 . This evidence is consistent with human capital theory, which defends that workers with less experience have a larger wage growth.

Summing up, empirical results indicate that industry- and occupation-specific skills are compensated by firms and this compensation is related with tenure. Comparing the quantitative relevance of industry and occupation skills, we observe that when a worker with 5 years of industry tenure switches sector (and maintains his occupation), his/ her wage declines by $3.2 \%$, i.e. $3.1 \%$ more than a worker who stays in the same industry and occupation. In contrast, a worker with 5 years of occupation tenure that changes occupation (and maintains his/her industry) loses $6 \%$ of his wage, i.e. his/her wage falls $4.4 \%$ more than that of a worker who stays in the same industry and occupation. This indicates that firms attach a slightly larger premium to occupation skills than to industry skills. $\left[{ }^{12}\right]$

Our results are in the line with those reported in the literature, but the intensity of wage loss is different. For instance, our estimate of $3.1 \%$ for the impact of five years of industry tenure is smaller than the estimate of Sullivan (2008) (6.4\%), but larger than that of Kambourov and Manovskii (2009) and Zangelidis (2008) for whom the impact of industry tenure on wages was not statistically different from zero. Our estimate of the impact of occupation-specific skills on wages (4.4\%) is larger than the estimate of Zangelidis (2008) (3.2\%), but it is smaller than those of Kambourov and Manovskii (2009) (12\% to 20\%) and Sullivan (2010) (6.8\%).

Empirical findings so far reported raise some doubts about the interaction between occupation and industry specific skills. If occupation-specific skills have a degree of industry specificity, then the wage loss associated with occupation tenure $\left(\beta_{2}\right)$ for a worker staying in the same occupation would be larger if the worker switches industry than if he stays in the same industry. A similar reasoning can be applied to industry tenure. If industry skills have a degree of occupation specificity, then the wage loss associated with industry tenure $\left(\beta_{1}\right)$ for a worker

12 Displaced workers may also lose wages due to the loss of firm-specific skills, which are obtained from firm tenure. This variable proves statistically insignificant in three of the four models, and is only significant if a worker stays in the same sector and occupation. In the latter case, firm tenure has a positive but small effect on wages: a five year tenure has a $0.5 \%$ impact on log wages. This may indicate that the hiring firm values firm experience acquired in other firms, probably with similar characteristics. However, in general, firm tenure has a small impact on wages, as other studies have pointed out (Sullivan, 2010).

DINÂMIA'CET - IUL, Centro de Estudos sobre a Mudança Socioeconómica e o Território ISCTE-IUL - Av. das Forças Armadas, 1649-026 Lisboa, PORTUGAL 
staying in the same industry would be larger if he changes occupation than if he stays in the same occupation.

However, our empirical test does not support this interaction. On the one hand, occupation skills do not have an industry specific component because when workers do not change occupation, $\beta_{2}$ is not statistically different from zero, whether or not the worker switches industry (models 2 and 4). On the other hand, industry skills do not have a significant occupation specific dimension, because when workers do not switch industry $\beta_{1}$ is not statistically different from zero whether or not the worker changes occupation (model 3 and 4).

Lastly, we examine wage losses across industries and occupations. Previous research has already pointed to differences in wages across industries caused by diverse valuations of industry-specific skills that do not accumulate with tenure, e.g. vocational skills learned outside the job like machining or computer skills (Kletzer, 1996). $\left[{ }^{13}\right]$ Shaw (1984) underlines that occupations such as managers and professionals and scientists invest more in human capital, which may lead to a bigger increase in wages with occupation tenure. Furthermore, some sectors may demand more specific knowledge from workers, resulting in a greater valuation of industry tenure. In order to explore different valuations of industry skills across industries, we focus our attention on models 2 and 4 where workers stay in the same industry. In this case, industry dummies indicate both the pre-displacement and the post-displacement industries. Next, we introduce an interaction term between industry tenure and industry dummy variables in order to capture the difference in the impact of pre-displacement industry tenure on wages across industries. The impact of industry tenure is $\mathrm{m}$ ost negative in the industries in which it is least valued. Here, the estimated coefficients indicate the proportional impact on wages of an additional year of industry tenure. A similar analysis is performed for occupational skills, focusing on models 3 and 4, where workers stay in the same occupation. In the equations for these models, an interaction term is added between occupation tenure and occupation dummies (CNP level 1) so that the impact of occupation tenure on wages can be differentiated for the various occupations. Since workers in model 4 do not change both industry and occupation, the equation for that model includes interaction terms between industry dummies and industry tenure, and occupation dummies and occupation tenure. Regarding occupation tenure, the results seem to indicate that the differentiation in the valuation of occupation tenure across occupations is greater when a worker switches industry than when he stays in the same industry

\footnotetext{
${ }^{13}$ Notice that these industry differences in wage growth do not arise from industry rents, because we are already controlling for differences in industry wage premiums. However, other factors may be behind differences in wage growth across industries, e.g. different demand for industry-specific skills. DINÂMIA'CET - IUL, Centro de Estudos sobre a Mudança Socioeconómica e o Território ISCTE-IUL - Av. das Forças Armadas, 1649-026 Lisboa, PORTUGAL Tel. 210464031 - Extensão 293100 E-mail: dinamia@iscte.pt www.dinamiacet.iscte.pt
} 
(Table 4). However, when the worker changes industry, statistically we cannot exclude occupation tenure having the same effect for all occupations (see test in Table 4). This result contrasts with that of Zangelidis (2008) where occupation tenure is more valued in professional, managerial and technical occupations. Sullivan (2010) also finds that occupational tenure is more relevant for professional occupations, but finds occupation experience has a negative effect on managers' wages.

The difference with Zangelidis (2008)'s results may be explained by the fact that his analysis included both displaced workers and other workers, while we focus only on the former. This could be important because high level occupations may benefit more from implicit contracts that guarantee high wages than low level occupations, or they may explore asymmetric information better to inflate their wages. These implicit contracts and informational advantages disappear when high level occupation employees change firms, explaining the lower valorisation of occupational tenure for these workers.

Table 4 - Different valuations of occupation tenure across occupations

\begin{tabular}{|c|c|c|}
\hline & $\begin{array}{l}2 \text { Switch } \\
\text { Industry } \\
\text { Stay } \\
\text { occupation }\end{array}$ & $\begin{array}{l}\text { S Stay } \\
\text { industry } \\
\text { Stay } \\
\text { occupation }\end{array}$ \\
\hline Occupation Tenure-OT & $\begin{array}{l}0.0017 \\
(0.0058)\end{array}$ & $\begin{array}{l}-0.0035 \\
(0.0027)\end{array}$ \\
\hline Interaction terms: & & \\
\hline OT*Managers & $\begin{array}{l}-0.0228 * * \\
(0.1005)\end{array}$ & $\begin{array}{l}0.0026 \\
(0.0051)\end{array}$ \\
\hline OT*Professionals and scientists & $\begin{array}{l}-0.0261 * * * \\
(0.0096)\end{array}$ & $\begin{array}{l}-0.0036 \\
(0.0058)\end{array}$ \\
\hline $\begin{array}{l}\text { OT*Middle management and } \\
\text { technicians }\end{array}$ & $\begin{array}{l}-0.0140 * * \\
(0.0056)\end{array}$ & $\begin{array}{l}-0.0041 \\
(0.0029)\end{array}$ \\
\hline $\begin{array}{l}\text { OT*Administrative and related } \\
\text { workers }\end{array}$ & $\begin{array}{l}-0.0144 * * * \\
(0.0028)\end{array}$ & $\begin{array}{l}-0.0036 * * \\
(0.0015)\end{array}$ \\
\hline OT*Service and sales workers & $\begin{array}{l}-0.0055 \\
(0.0045)\end{array}$ & $\begin{array}{l}-0.0002 \\
(0.0019)\end{array}$ \\
\hline OT*Machine operators and & $-0.0104 * *$ & -0.0010 \\
\hline assembly workers & $(0.0044)$ & $(0.0020)$ \\
\hline OT*Unskilled workers & $\begin{array}{l}-0.0103 * * \\
(0.0048)\end{array}$ & $\begin{array}{l}-0.0019 \\
(0.0021)\end{array}$ \\
\hline $\begin{array}{l}\text { All interaction terms equal to } \\
\text { zero- Chi squared ( } 7) \text { and p- } \\
\text { value }\end{array}$ & $\begin{array}{l}43.10 \\
(0.0000)\end{array}$ & $\begin{array}{l}8.62 \\
(0.2811)\end{array}$ \\
\hline $\begin{array}{l}\text { All Interaction terms equal - Chi } \\
\text { squared (6) and p-value }\end{array}$ & $\begin{array}{l}10.28 \\
(0.1133)\end{array}$ & $\begin{array}{l}5.25 \\
(0.5120)\end{array}$ \\
\hline
\end{tabular}

Notes: base category - skilled workers and craftsmen. The variables included in $\mathbf{x}_{1 \mathbf{t}}$ (eq. 1) are also considered. In model 4 the interaction terms between industry tenure and industry dummies are also included. The multinomial logit model was used to correct selection bias. $* * *$ - significant at $1 \%, * *$ significant at $5 \%$. 
In turn, differences in the valuation of industry tenure across industries are clearer when a worker stays in the same occupation and industry than when he changes occupation in the same industry (Table 5). In both cases, the variations in the value of industry tenure are not statistically the same across industries and they are not simultaneously equal to zero (see tests in Table 5). The estimates from model 4 indicate that industry-specific skills are particularly valued by banking and finance, while sectors like extractive industries, real estate and services to firms, transport, and collective and social services are not concerned with these skills. Notice that real estate and service to firms also have a very low valuation of industry tenure when a worker changes occupation $(-1.3 \%)$ - Model 3 . The sectors in model 4 with an average valuation of industry tenure (where the interaction terms are not significantly different from zero) are: manufacturing, construction, trade, and restaurants and hotels. Industry tenure in trade is much less valued if a worker changes occupation $(-0.5 \%)$. Our results the findings by Kletzer (1996) and Zangelidis (2008) that reported the relevance of industry-specific skills in trade, banking and finance. Furthermore, the estimates reported in Table 5 indicate that in some other sectors, industry tenure is only rewarded when a worker stays in the same occupation. This is particularly the case of the trade sector.

\section{CONCLUDING REMARKS}

The goal of this paper was to explore the relevance of industry- and occupation-specific skills using workers who were displaced following a firm's closure. This topic emerged in the late 1980s but needs to be revisited and given greater political relevance. Our study used this particular set of workers because the decision to change firm is exogenous. The empirical strategy targeted the comparison of wage loss associated with industry/occupation tenure between industry/occupation switchers and stayers.

Our results indicate that both industry and occupation specific skills are valued by firms. Firstly, pre-displacement industry/occupation tenure prevents worker from moving sector/occupation. Occupation tenure has a greater impact on preventing workers from changing occupation than industry tenure on hindering workers from changing industry.

Secondly, workers that change industry/occupation have a bigger wage loss due to their pre-displacement industry/occupation tenure than industry/occupation stayers. This indicates that workers lose the remuneration associated with their industry/occupation specific skills when they change industry/occupation. Furthermore, firms attach a slightly larger wage premium to occupation skills than to industry skills. These findings suggest that occupations 
have more specific skills needs than industries. This evidence is somehow intuitive because formal and informal training is usually occupation-based rather than industry-based.

Table 5 - Differences in industry tenure valuation across industries

\begin{tabular}{|c|c|c|}
\hline & $\begin{array}{l}3 \text { Stay } \\
\text { industry } \\
\text { Switch } \\
\text { occupation }\end{array}$ & $\begin{array}{l}4 \text { Stay } \\
\text { industry } \\
\text { Stay } \\
\text { occupation }\end{array}$ \\
\hline Industry Tenure - IT & $\begin{array}{l}0.0005 \\
(0.0020)\end{array}$ & $\begin{array}{l}0.0008 \\
(0.0012)\end{array}$ \\
\hline Interaction terms: & & \\
\hline IT*Extractive industries & $\begin{array}{l}-0.0060 \\
(0.0086)\end{array}$ & $\begin{array}{l}-0.0072 * \\
(0.0036)\end{array}$ \\
\hline IT*Construction & $\begin{array}{l}-0.0011 \\
(0.0013)\end{array}$ & $\begin{array}{l}-0.00059 \\
(0.0008)\end{array}$ \\
\hline IT $^{*}$ Trade & $\begin{array}{l}-0.0049 * * * \\
(0.0012)\end{array}$ & $\begin{array}{l}-0.0008 \\
(0.0007)\end{array}$ \\
\hline IT*Restaurants and hotels & $\begin{array}{l}-0.0021 \\
(0.0026)\end{array}$ & $\begin{array}{l}-0.0007 \\
(0.0012)\end{array}$ \\
\hline IT $^{*}$ Transport & $\begin{array}{l}-0.0026 \\
(0.0032)\end{array}$ & $\begin{array}{l}-0.0045^{* *} \\
(0.0018)\end{array}$ \\
\hline IT*Banking and finance & $\begin{array}{l}0.00005 \\
(0.00203)\end{array}$ & $\begin{array}{l}0.0031 * * * \\
(0.0009)\end{array}$ \\
\hline $\begin{array}{l}\text { IT*Real estate and services to } \\
\text { firms }\end{array}$ & $\begin{array}{l}-0.0133 * * * \\
(0.0036)\end{array}$ & $\begin{array}{l}-0.0051 * * \\
(0.0022)\end{array}$ \\
\hline IT*Collective and social services & $\begin{array}{l}-0.0002 \\
(0.0210)\end{array}$ & $\begin{array}{l}-0.0047 * * * \\
(0.0015)\end{array}$ \\
\hline $\begin{array}{l}\text { All interaction terms equal to } \\
\text { zero- Chi squared ( } 8) \text { and p- } \\
\text { value }\end{array}$ & $\begin{array}{l}38.57 \\
(0.0000)\end{array}$ & $\begin{array}{l}33.02 \\
(0.0001)\end{array}$ \\
\hline $\begin{array}{l}\text { All Interaction terms equal - Chi } \\
\text { squared (7) and p-value }\end{array}$ & $\begin{array}{l}34.68 \\
(0.0000)\end{array}$ & $\begin{array}{l}31.91 \\
(0.0000)\end{array}$ \\
\hline
\end{tabular}

Notes: base category - manufacturing. The variables included in $\mathbf{x}_{1 \mathrm{t}}$ (eq. 1) are also considered. In model 4 the interaction terms between occupation tenure and occupation dummies are also included. The multnomial logit model was used to correct selection bias. $* * *$ - significant at $1 \%$, ** - significant at $5 \%$. * significant at $1 \%$.

Empirical findings suggest that industry-specific skills are valued differently across industries, while occupation-specific skills have a more homogenous valuation over occupations. Our results, like others, indicate that some sectors tend to reward industry tenure more than others, notably banking and finance (Kletzer, 1996). On the other hand, in contrast to other studies such as Zangelidis (2008), our results reveal that managers and professional occupations are not given better compensation for occupation tenure than other occupations. This may be related with the loss of their informational power and implicit contracts in the pre-displacement firm, rather than the loss of specific skills.

DINÂMIA'CET - IUL, Centro de Estudos sobre a Mudança Socioeconómica e o Território ISCTE-IUL - Av. das Forças Armadas, 1649-026 Lisboa, PORTUGAL 
This finding should be given further attention in future research. It would also be interesting to study why workers who simultaneously change industry and occupation are less penalised than those changing only one or the other. It is probable that this is because new industries and new occupations provide better job opportunities than uncompetitive industries and obsolete occupations. However, this career change usually involves training for new qualifications.

Policy makers should be concerned with involuntary job mobility in the labour market, especially with the usefulness of acquired skills, and the time taken to acquire new skills in post-displacement jobs. Lost skills might be hardly compensated by fast training in some job specific skills (Ohlsson and Storrie, 2012). In a context of rising unemployment, our analysis allows us to suggest that experienced workers that are displaced and forced to find a job in a different industry suffer considerable wage cuts, which is even greater if they have to find a job in a different occupation. Ultimately, displacement is costly not only for people, but also for the society. In addition to re-employment policies, labour market players should focus on measures that enhance the transferability of accumulated skills and the acquisition of new skills. For instance, public employment services should have experts with technical skills and tools to provide assistance and counseling on career changes.

DINÂMIA'CET - IUL, Centro de Estudos sobre a Mudança Socioeconómica e o Território ISCTE-IUL - Av. das Forças Armadas, 1649-026 Lisboa, PORTUGAL 


\section{REFERENCES}

Abowd, J. M., Kramarz, F. and Margolis, D. N. (1999),"High wage workers and high wage firms", Econometrica, Vol. 67 No. 2, pp. 251-333.

Addison, J. T. and Portugal, P. (1989), "Job Displacement, Relative Wage Changes, and Duration of Unemployment." Journal of Labor Economics, Vol 7 No. 3, pp. 281-302.

Blanchard, O. and Portugal, P. (2001), "What hides behind an unemployment rate: comparing Portuguese and U.S. labor markets", The American Economic Review, Vol. 91(1), pp. 187-207.

Becker, G. (1964), Human Capital, The University of Chicago Press, Chicago and London.

Bono, E.D. and Vuri, D. (2011), "Job mobility and the gender wage gap in Italy", Labour Economics, vol.18: 130-142.

Bourguignon, F., Fournier, M., and Gurgand, M. (2007), "Selection bias corrections based on the multinomial logit model: Monte-Carlo comparisons", Journal of Economic Survey, Vol. 21 (1), pp. 174-205.

Brown, C. and Medoff, J. (1989), "The Employer Size-Wage Effect", Journal of Political Economy, Vol. 97(5), pp. 1027-1059.

Cardoso, A.R. and Portugal, P. (2005), "Contractual Wages and the Wage Cushion under Different Bargaining Settings”, Journal of Labor Economics, Vol. 23 No. 4, pp. 875-901.

Cardoso, A.R., and Portela, M. (2009), "Micro Foundations for Wage Flexibility: Wage Insurance at the Firm Level", Scandinavian Journal of Economics, Vol. 111 No. 1, pp. 29-50.

Carneiro, A, and Portugal, P. (2006), "Earnings losses of displaced workers: Evidence from matched employer-employee data set”, IZA Discussion Paper nº 2289, IZA.

Cha, Y., and Morgan, S.L. (2010), "Structural Earnings Losses and Between-Industry Mobility of Displaced Workers, 2003-2008”, Social Science Research, Vol. 39, pp. 1137-1152.

DINÂMIA'CET - IUL, Centro de Estudos sobre a Mudança Socioeconómica e o Território ISCTE-IUL - Av. das Forças Armadas, 1649-026 Lisboa, PORTUGAL Tel. 210464031 - Extensão 293100 E-mail: dinamia@iscte.pt www.dinamiacet.iscte.pt 
Devereux, P.J. and Hart,R.A. (2006), "Real wage cyclicality of job stayers, within-company job movers, and between-company job movers", Industrial and Labor Relations Review, Vol. 1, pp. 105-119.

Dolton, P. and Kidd, M. (1998), "Job changes, occupational mobility and human capital acquisition: An empirical analysis”, Bulletin of Economic Research, Vol. 50 No. 4.

Fallick, B.C. (1996), "A review of the recent empirical literature on displaced workers", Industrial and Labor Relations Review, Vol. 50 No. 1, pp. 118-129.

Farber, H.S. (1999), "Mobility and stability: The dynamics of job change in labor markets", in O. Ashenfelter and D.E. Card (eds.) Handbook of Labor Economics, North-Holland, Amsterdam, 3B, Ch 37, pp. 2439-2483.

García Pérez, J.I. and Rebollo Sanz, Y. (2005), Wage changes through job mobility in Europe: A multinomial endogenous switching approach, Labour Economics 12(4), 531-555.

Goldsmith, A. H. and Veum, J. R. (2002), "Wages and the composition of experience", Southern Economic Journal, Vol. 69, pp. 429-43.

Jacobson, L. S., LaLonde, R. J., and Sullivan, D. G. (1993), The Costs of Worker Dislocation. Kalamazoo, Ml: W. E. Upjohn Institute for Employment Research.

Kambourov, G. and Manovskii, I. (2009), "Occupational Specificity of Human Capital", International Economic Review, Vol. 50 No. , pp. 63-115.

Kletzer, L. (1996), "The Role of Sector-Specific Skills in Postdisplacement Earnings", Industrial Relations, Vol. 35 No. 4, pp. 473-490.

Lazear, E.P. (2003), "Firm-Specific Human Capital: A Skill-Weights Approach". NBER Working Paper No. 9679, NBER.

Lima, F. and Pereira, P. T. (2003), "Careers and wages within large firms: evidence from a matched employer-employee data set”, International Journal of Manpower, Vol. 24 No. 7, pp. 812-835.

DINÂMIA'CET - IUL, Centro de Estudos sobre a Mudança Socioeconómica e o Território ISCTE-IUL - Av. das Forças Armadas, 1649-026 Lisboa, PORTUGAL 
Markey, J. P. and Parks, W. (1989), “Occupational change: pursuing a different kind of work”, Monthly Labor Review, Sep., pp. 3-12.

Martins, P. S. (2007), "Heterogeneity in real wage cyclicality", Scottish Journal of Political Economy, Vol 54 No. 5, pp 684-698.

Neal, Derek (1995), "Industry-Specific Human Capital: Evidence from displaced workers", Journal of Labor Economics, Vol. 13 No. 4.

Neumark, D. and Taubman, P. (1994) Why do wage profiles slope upwards? Tests of the general human capital model, NBER Working Paper, 4688.

Ohlsson, H. and Storrie, D. (2012), "Long term effects of public policy for displaced workers in Sweden - shipyard workers in the West and miners in the North", International Journal of Manpower, Vol. 33 Issue 5, pp. 514-539.

Ong, P. M. and Mar, D. (1992), "Post-Layoff Earnings Among Semiconductor Workers" Industrial and Labor Relations Review, Vol. 45 No. 2, pp. 366-79.

Parent, D. (2000), "Industry-specific capital and the wage profile: evidence from National Longitudinal survey of Youth and the Panel Study of Income Dynamics", Journal of Labor Economics, Vol. 18 No. 2, pp. 306-323.

Podgursky, M. and Swaim, P. (1987), "Job Displacement and Earnings Loss: Evidence from the Displaced Workers Survey”, Industrial and Labor Relations Review, Vol. 41 No. 1, pp. 17-29.

Poletaev, M. and Robinson, C. (2008), "Human capital specificity: Evidence from the dictionary of occupational titles and displaced workers surveys, 1984-2000", Journal of Labor Economics, Vol. 26 No.3, pp. 387-420.

Shaw, K. L. (1984), "A formulation of the earnings function using the concept of occupational investment”, Journal of Human Resources, Vol. 19 No. 3, pp. 319-340.

Stevens, M. (1996), "Transferable Training and Poaching Externalities", in A.L. Booth and D.J. Snower (eds.) Acquiring Skills: Market Failures, their Symptoms and Policy Responses, Press Syndicate of the University of Cambridge, Cambridge, pp. 19-40.

DINÂMIA'CET - IUL, Centro de Estudos sobre a Mudança Socioeconómica e o Território ISCTE-IUL - Av. das Forças Armadas, 1649-026 Lisboa, PORTUGAL Tel. 210464031 - Extensão 293100 E-mail: dinamia@iscte.pt www.dinamiacet.iscte.pt 
Sullivan, P. (2010), "Empirical evidence on occupation and industry specific human capital", Labour Economics, Vol. 17 No. 3, pp. 567-580.

Thurow, L. (1976), Generating inequality, USA, Macmillan Publishers Limited.

Zangelidis, A. (2008), "Occupational and Industry Specificity of Human Capital in the British Labour Market”, Scottish Journal of Political Economy, Vol. 55 No. 4, pp. 420-443. 


\section{ANNEX}

We used the level 1 Classification of Economic Activities (CAE) of the National Institute of Statistics (INE). We maintained the coherence of the classification across the 4 revisions. In Revision 3, industries used in this paper include the following codes: Extractive industry (B), manufacturing (C), Construction (F), Trade (G), Restaurants and Hotels (I), Transport (H, except postal activities (53)), Banks and finance (K), Real estate and services to firms ( $\mathrm{L}$ - real estate, $\mathrm{M}$ - consulting and scientific activities, $\mathrm{N}$ - Administrative activities, J- information and communication, and 53 - postal activities), and social services (P - Education, Q - Health, RArts and sports, $\mathrm{S}$ - Other services, $\mathrm{T}$ - Household activities, and $\mathrm{U}$ - International organisations). Electricity and other utilities, and agriculture were not included. Electricity and other utilities were excluded because of the small number of displaced workers and Agriculture was excluded because of the importance of non-monetary remunerations, which the data does not capture.

Tables:

Table A1 - Summary statistics

\begin{tabular}{|c|c|c|c|c|}
\hline Variable & Mean & Std. Dev. & Min & Max \\
\hline$\Delta w_{i t}$ & 0.066687 & 0.359645 & -1.23887 & 1.365051 \\
\hline Change unemployment rate & 0.002001 & 0.007346 & -0.018 & 0.013 \\
\hline Years since displacement & 1.194459 & 1.684456 & 0 & 11 \\
\hline$T$ & 2003.644 & 3.368667 & 1996 & 2008 \\
\hline Female & 0.437543 & 0.496085 & 0 & 1 \\
\hline Years of schooling & 7.565381 & 3.538874 & 0 & 16 \\
\hline Difference in number workers & 0.810257 & 2.051535 & -8.66147 & 9.894598 \\
\hline Difference in sales per worker & -0.11917 & 1.52631 & -11.413 & 10.41212 \\
\hline Labour market experience & 18.12868 & 9.873533 & 0 & 49 \\
\hline Firm tenure & 4.278898 & 5.822716 & 0 & 47 \\
\hline Industry Tenure & 5.755531 & 5.741898 & 0 & 48 \\
\hline Occupation Tenure & 3.134517 & 2.321226 & 1 & 12 \\
\hline \multicolumn{5}{|l|}{ Occup. dummies (post-displac.): } \\
\hline Managers & 0.016884 & 0.128838 & 0 & 1 \\
\hline Professionals and scientists & 0.022463 & 0.148183 & 0 & 1 \\
\hline Middle manager and tech. & 0.073385 & 0.260767 & 0 & 1 \\
\hline Admin. and related workers & 0.130502 & 0.336856 & 0 & 1 \\
\hline Service and sales & 0.164127 & 0.370391 & 0 & 1 \\
\hline Skilled workers and craftsmen & 0.343544 & 0.474892 & 0 & 1 \\
\hline $\begin{array}{l}\text { Machine Operator and } \\
\text { assembly }\end{array}$ & 0.101635 & 0.302168 & 0 & 1 \\
\hline Unskilled workers & 0.147461 & 0.354566 & 0 & 1 \\
\hline Indus. Dummies (post-displac.): & & & & \\
\hline
\end{tabular}




\begin{tabular}{l|c|c|c|c} 
Extractive & 0.005075 & 0.07106 & 0 & 1 \\
Manufacturing & 0.291885 & 0.454631 & 0 & 1 \\
Construction & 0.193677 & 0.395179 & 0 & 1 \\
Trade & 0.223252 & 0.416427 & 0 & 1 \\
Restaurants and hotels & 0.066765 & 0.249616 & 0 & 1 \\
Transport & 0.041787 & 0.200104 & 0 & 1 \\
Banking and finance & 0.016815 & 0.128577 & 0 & 1 \\
Real est. and serv. to firm & 0.111257 & 0.314451 & 0 & 1 \\
Collective and social services & 0.049488 & 0.216884 & 0 & 1 \\
Diff. wage prem. & 0.010635 & 0.138413 & -1.2086 & 1.1936 \\
\hline $\mathrm{N}$ & \multicolumn{5}{|c}{200778} \\
\hline
\end{tabular}

Table A2 - Distribution of workers by industry

\begin{tabular}{|c|c|c|c|}
\hline & $\begin{array}{c}\text { Pre- } \\
\text { displacement }\end{array}$ & $\begin{array}{c}\text { Post- } \\
\text { displacement }\end{array}$ & Difference \\
\hline Extractive & 0.0043 & 0.0051 & 0.0008 \\
Manufacturing & 0.3289 & 0.2919 & -0.0370 \\
Construction & 0.1978 & 0.1937 & -0.0041 \\
$\begin{array}{c}\text { Trade } \\
\text { Restaurants } \\
\text { and hotels }\end{array}$ & 0.2266 & 0.2233 & -0.0033 \\
$\begin{array}{c}\text { Transport } \\
\text { Banking and } \\
\text { finance }\end{array}$ & 0.0738 & 0.0668 & -0.0070 \\
$\begin{array}{c}\text { Real estate } \\
\text { and service to } \\
\text { firms }\end{array}$ & 0.0350 & 0.0418 & 0.0068 \\
$\begin{array}{c}\text { Collective and } \\
\text { social services }\end{array}$ & 0.0275 & 0.0168 & 0.0006 \\
\hline Total & 1 & 0.1113 & 0.0212 \\
\hline
\end{tabular}

DINÂMIA'CET - IUL, Centro de Estudos sobre a Mudança Socioeconómica e o Território ISCTE-IUL - Av. das Forças Armadas, 1649-026 Lisboa, PORTUGAL 
Table A3 - Distribution of workers by occupation

\begin{tabular}{|c|c|c|c|}
\hline & $\begin{array}{c}\text { Pre- } \\
\text { displacement }\end{array}$ & $\begin{array}{c}\text { Post- } \\
\text { displacement }\end{array}$ & Difference \\
\hline Managers & 0.0205 & 0.0169 & -0.0036 \\
\hline $\begin{array}{c}\text { Profession. } \\
\text { and scient. }\end{array}$ & 0.0196 & 0.0225 & 0.0029 \\
\hline $\begin{array}{c}\text { Middle } \\
\text { manag. and } \\
\text { technicians }\end{array}$ & 0.0704 & 0.0734 & 0.0030 \\
\hline $\begin{array}{c}\text { Administ. and } \\
\text { related } \\
\text { workers }\end{array}$ & 0.1307 & 0.1305 & -0.0002 \\
\hline $\begin{array}{c}\text { Service and } \\
\text { sales work. }\end{array}$ & 0.1619 & 0.1641 & 0.0023 \\
\hline $\begin{array}{c}\text { Skilled work. } \\
\text { and craftsmen }\end{array}$ & 0.3687 & 0.3435 & -0.0252 \\
\hline $\begin{array}{c}\text { Machine } \\
\text { operat. and } \\
\text { assembly }\end{array}$ & 0.0972 & 0.1016 & 0.0044 \\
\hline $\begin{array}{c}\text { Unskilled } \\
\text { workers }\end{array}$ & 0.1310 & 0.1475 & 0.0165 \\
\hline Total & 1 & 1 & \\
\hline
\end{tabular}

Table A4 - Type of decision by industry

\begin{tabular}{|c|c|c|c|c|c|c|c|}
\hline & \multirow[b]{2}{*}{$\begin{array}{c}\text { No. } \\
\text { workers }\end{array}$} & \multicolumn{4}{|c|}{ Type of decision } & \multicolumn{2}{|c|}{$\begin{array}{l}\text { Type of decision in terms } \\
\text { of industry }\end{array}$} \\
\hline & & $\begin{array}{l}\text { 1. Move } \\
\text { ind. and } \\
\text { occup. }\end{array}$ & $\begin{array}{l}\text { 2. Move } \\
\text { ind. and } \\
\text { stay } \\
\text { occup. }\end{array}$ & $\begin{array}{l}\text { 3. Stay } \\
\text { ind. and } \\
\text { move } \\
\text { occup. }\end{array}$ & $\begin{array}{l}\text { 4. Stay ind. } \\
\text { and occup. }\end{array}$ & $\begin{array}{c}\text { Move } \\
\text { industry } \\
(1+2)\end{array}$ & $\begin{array}{c}\text { Stay } \\
\text { industry } \\
(3+4)\end{array}$ \\
\hline Extractive & 858 & 0.255 & 0.249 & 0.141 & 0.354 & 0.505 & 0.495 \\
\hline Manufacturing & 66031 & 0.217 & 0.082 & 0.203 & 0.498 & 0.299 & 0.701 \\
\hline Construction & 39707 & 0.147 & 0.083 & 0.203 & 0.568 & 0.230 & 0.770 \\
\hline Trade & 45488 & 0.252 & 0.109 & 0.239 & 0.400 & 0.361 & 0.639 \\
\hline $\begin{array}{l}\text { Restaurants } \\
\text { and hotels }\end{array}$ & 14818 & 0.333 & 0.095 & 0.108 & 0.465 & 0.427 & 0.573 \\
\hline Transport & 7025 & 0.169 & 0.143 & 0.096 & 0.592 & 0.311 & 0.689 \\
\hline $\begin{array}{l}\text { Banking and } \\
\text { finance }\end{array}$ & 3257 & 0.131 & 0.069 & 0.233 & 0.567 & 0.200 & 0.800 \\
\hline $\begin{array}{l}\text { Real estate } \\
\text { and service to } \\
\text { firms }\end{array}$ & 18082 & 0.254 & 0.199 & 0.173 & 0.374 & 0.453 & 0.547 \\
\hline $\begin{array}{l}\text { Collective and } \\
\text { social services }\end{array}$ & 5512 & 0.279 & 0.112 & 0.165 & 0.444 & 0.392 & 0.608 \\
\hline Total & 200778 & & & & & & \\
\hline
\end{tabular}

DINÂMIA'CET - IUL, Centro de Estudos sobre a Mudança Socioeconómica e o Território 
Table A5 - Type of decision by occupation

\begin{tabular}{|c|c|c|c|c|c|c|c|}
\hline & \multirow[b]{2}{*}{$\begin{array}{c}\text { No. } \\
\text { workers }\end{array}$} & \multicolumn{4}{|c|}{ Type of decision } & \multicolumn{2}{|c|}{$\begin{array}{c}\text { Type of decision in terms of } \\
\text { occupation }\end{array}$} \\
\hline & & $\begin{array}{l}\text { 1. Move } \\
\text { ind. and } \\
\text { occup. }\end{array}$ & $\begin{array}{l}\text { 2. Move } \\
\text { ind. and } \\
\text { stay } \\
\text { occup. }\end{array}$ & $\begin{array}{c}\text { 3. Stay } \\
\text { ind. and } \\
\text { move } \\
\text { occup. }\end{array}$ & $\begin{array}{l}\text { 4. Stay } \\
\text { ind. and } \\
\text { occup. }\end{array}$ & $\begin{array}{c}\text { Move } \\
\text { occupation } \\
(1+3)\end{array}$ & $\begin{array}{c}\text { Stay in } \\
\text { occupation } \\
(2+4)\end{array}$ \\
\hline - Managers & 4110 & 0.323 & 0.078 & 0.346 & 0.252 & 0.670 & 0.330 \\
\hline $\begin{array}{l}\text { - Profession. } \\
\text { and scient. }\end{array}$ & 3936 & 0.232 & 0.150 & 0.245 & 0.373 & 0.477 & 0.523 \\
\hline $\begin{array}{l}\text { - Middle } \\
\text { manag. and }\end{array}$ & 14138 & 0.252 & 0.131 & 0.275 & 0.341 & 0.527 & 0.473 \\
\hline $\begin{array}{l}\text { - Administ. } \\
\text { and related } \\
\text { workers }\end{array}$ & 26251 & 0.247 & 0.194 & 0.226 & 0.334 & 0.472 & 0.528 \\
\hline $\begin{array}{l}\text { - Service and } \\
\text { sales work. }\end{array}$ & 32497 & 0.289 & 0.072 & 0.155 & 0.484 & 0.444 & 0.556 \\
\hline $\begin{array}{l}\text { SKIIled } \\
\text { work. and } \\
\text { craftsmen }\end{array}$ & 74026 & 0.159 & 0.074 & 0.141 & 0.626 & 0.300 & 0.700 \\
\hline $\begin{array}{l}\text { - Machine } \\
\text { operat. and } \\
\text { assembly }\end{array}$ & 19517 & 0.230 & 0.129 & 0.215 & 0.427 & 0.445 & 0.555 \\
\hline $\begin{array}{l}\text { - Unskilled } \\
\text { workers }\end{array}$ & 26303 & 0.250 & 0.097 & 0.290 & 0.363 & 0.540 & 0.460 \\
\hline Total & 200778 & & & & & & \\
\hline
\end{tabular}

DINÂMIA'CET - IUL, Centro de Estudos sobre a Mudança Socioeconómica e o Território 